\title{
The Impact of Federal Character Principles on National Integration in the Selected Federal Tertiary Institutions in Nigeria
}

\author{
Dr. Lucky Benson ${ }^{1}$, Yusuf Musa Audu ${ }^{2}$ \\ ${ }^{1}$ Department of Political Science and Administration, Faculty of Social Science, Adamawa State University Mubi, Nigeria \\ ${ }^{2}$ Registry Department, College for Legal Studies Yola, Nigeria
}

\begin{abstract}
The complexity of Nigeria's multi-ethnic and multireligious nature as well as its political history before and after independence makes it increasingly necessary for country to identify a workable formula for the peaceful coexistence of its people. Principle of federal character is aimed at ensuring fairness and equity in the distribution of public posts and socioeconomic infrastructures among the various agencies of government including higher education institutions in the country. The aim of this study is to investigate the level of compliance with federal character principles as well as analyse the factors hindering strict adherence to these principles in the federal higher education institutions situated in Adamawa state. A descriptive survey design was adopted in which 123 staff of the selected institutions was used as research subjects. The collected data was analysed using descriptive and inferential statistics with help of SPSS version 23. Findings of the study reveals that there is a high level of awareness of the principle of federal character among employees of federal institutions. There seems to be strong and general acceptance amongst scholars that the whole essence of the establishment of the federal character principles as a policy is to ensure equitable distribution of governmental activities and employments in the country. However, the practical implementation and interpretation of this policy is far from it main objectives. Among the factors hindering strict adherence to these principles include ethnicity, tribalism, external influence, favouritism and to a considerable extent corruption. Looking at the factors that affect the smooth implementation, enforcement and strict compliance with the federal character principles in the federal institutions, we recommend that relevant provisions of the constitution should be amended so as to make all the key policy actors to implement the federal character principles in tertiary institutions across Nigeria. Also, strict adherence to policy guideline and implementation plans as spelled out in the Act establishing the federal character principles must be clearly followed in order to end inequality and marginalisation. Finally, an enforcement unit of the federal character principles should be strengthening in order to carryout it duty of ensuring equitable distribution of employment and fairness and sanction should be carryout on those institutions that violate any part of the principles.
\end{abstract}

Keywords: Federal character, National integration, Higher education institutions, Nigeria

\section{INTRODUCTION}

$\mathrm{F}$ ederal tertiary institutions can be seen as institutions that are established, controlled, funded and managed by the federal government. Nigeria has many federal tertiary institutions across the country comprising of universities, polytechnics, monotechnics and colleges of education. Here in Adamawa state, there are three federal tertiary institutions. These are Modibbo Adama University of Technology, Yola, Federal Polytechnic, Mubi and Federal College of Education Yola. Federal character principles are aimed at ensuring fairness and equity in the distribution of public posts and socio-economic infrastructures among the various federating units including these institutions in the country. This policy was adopted by the government on good intention in other to bring a balance in the areas of appointments of principal officers, recruitment of staff, students' enrolment, sharing of national or state allocations among others due to the plurality of Nigeria as a country.

Given the complexity of Nigeria's multi-religious and multiethnic State as well as its political history before and after independence, it became increasingly necessary for Nigerians to fashion out a workable formula for the peaceful coexistence of its people. For instance, in the Northern part of the country alone, there are the Hausas, the Fulanis, the Kanuris, Igbiras, Igalas and many others. In the Southern part of the country are the Yorubas, the Edos, the Urhobos, the Igbos, the Ibibios, the Ijaws and other small ethnic groups. Each group not only inhabits a particular geographical area but has its own language, cultural heritage and affiliations. For these multiethnic and multi-religious people to live together in peace and harmony, have equal opportunity to represent and be represented, access equitable distribution of national resources, promote national unity, foster national loyalty, the administration of the country should give every citizen a sense of belonging to the nation.

Despite the diversities of ethnic origin, cultural, language or religion, Nigerian government must put in place principles that will guide the conduct of its affairs. These principles according to Adeosun, (2011) reflect the federal character of Nigeria and the need to promote national unity, command national loyalty, thereby ensuring that there shall be no predominance of persons from few states or ethnic or other sectional groups in running the affairs of the government or any of its agencies. For a country like Nigeria to avert ethnic or sectional groups dominance, Adesoji, and Alao, (2009) 
remarked that the composition of the government of a state, a local government council, or any of the agencies should be carried out in such a manner as to recognize the diversity of the people within its area of authority and the need to promote a sense of belonging and loyalty among all the people of the federation. It is for this singular reason that the Government through Constitution put in place a principle referred to as the "Federal Character Principle or Quota System" which states expressly that "...the desire of the people of Nigeria to promote national integration, foster national unity and give citizens a sense of belonging as enshrined in Section 14 (3 \& 4) of the 1999 Constitution of the Federal Republic of Nigeria as amended (FRN, 1999). The federal character is a deliberate design to accommodate less dominant but often forcibly expressed interest. Ezeibe (2013) posits that federal character principle involves a deliberate plan to construct means of ensuring the proper distribution of amenities and government projects in a country. Implicit in the above definitions is that federal character is introduced where there are observed differences in culture, tradition and inequality either in human, natural or both.

Therefore, federal character is a palliative principle aimed at uniting once existed autonomous sub-nationalities through quota system for purposes of equality of opportunities and peaceful co-existence. Heirmexy, (2011) noted that federal character was introduced for equitable sharing of posts and even distribution of natural and economic resources. In his own contribution, Ezeibe, (2013: add page number) contends that federal character principle is a political settlement that enables every section of the Nigerian society to be represented in government.

The Nigerian government has for quite a long time been resorting to series of measures in a quest for ethnic balancing and fair representation in Federal institutions among the various interest groups in the Federation. However, in Adamawa State, there are still ethnic groups or segments of the Federation that continue to wail for being marginalized by the privileged ethnic groups or sections of this country mostly in terms of appointment of vice chancellors and provost of the colleges, employment opportunity, offer of admission into federal educational institutions, citing of federal government institution as well as the sharing of national resources. These Phenomenon remain a contentious issue facing Nigerian federalism. This study is poised to assess the impact of federal character principles on National integration in selected institutions in Adamawa State.

Review of extant literature on federal character principles showed that scholars focused their attention more on ministries, departments and agencies of federal government paying less attention to educational institutions (Adeosun, 2011; Ezeibe, 2013; Ibada \& Okolo, 2009). Again, most of these studies were conducted in southern part of this country (Ibeto \& Aremu, 2013; Okolo, 2014). This study is however aimed at bridging this gap by investigating the level of compliance with these principles on appointments of principal officers, staff recruitment, students' enrollment and exploring the factors hindering strict adherence to these principles in federal tertiary institutions in Adamawa state.

This study will specifically focus on the Federal character principle on national integration in the appointment of vice chancellors and provost of the colleges, employment opportunity, offer of admission into federal educational institutions, citing of federal government institutions in Adamawa State. The study restricts its courage only to federal government institution in Adamawa State from the period of 2014 - 2018 Modibbo Adama University of Technology, Yola, Federal College of Education, Yola.

\section{LITERATURE REVIEW}

\section{Concept of National Integration in Nigeria}

National Integration (NI) refers to the awareness of a common identity amongst the citizens of a country. It means that though we belong to different castes, religions and regions and speak different language, we recognize the fact that we are all one. Nigeria is a country with about 250 ethnic nationalities distinctively isolated in terms of religion and languages. NI implies that we should de-emphasize these differences and promote such policies that could unite Nigeria. Etekpe, and Okolo, (2011) observed that introduction of Unity Schools, National Youth Service Corps (NYSC) state creation, quota system are some of the policies aimed at achieving NI. Okorie, (2009), see the process of creating unity and sense of belonging among heterogeneous groups in the state.

In the view of Wikipedia, (2013), it refers to the process of constructing a national identity using the power of the state. It further stated that it involves the process aimed at unification of the people within the state so that it remains politically stable and viable in the long run. The concept gained popularity due to the observed diversity in culture, tradition and religion in Nigeria after amalgamation and 1960 independence. It became obvious that the existence of Nigeria is marriage of divergent bed fellows and so its corporate existence hinges on advocacies and policy trust that can restore confidence, safety and sense of accommodation irrespective of the differences. Federal character/quota system is one of the principles and policies introduced to guarantee peaceful coexistence.

\section{The Federal Character Principles}

Federal Character as defined by Ezeibe, (2012), is a deliberate plan to construct means of ensuring the proper distribution of amenities and government projects in a country. Implicit in the above definition is that FC is introduced where there are observed differences in culture, tradition and inequality either in human, natural or both. Therefore, FC is a palliative principle aimed at uniting once existed autonomous subnationalities through quota system for the purposes of equality of opportunities and peaceful co-existence. Heirmexy (2011) noted that FC was introduced for equitable sharing of posts 
and even distribution of natural and economic resources. Contextually, the policy evolved through three main phases: implied, expressed and applied/ practiced. From 1914-1953, the principle was saliently applied as encapsulated by the amalgamation policy, however, from 1953-1976, it was applied under federalism, introduced in 1954. From 1976 to date, the principle is constitutionalized and fully practiced in the country.

Etekpe, and Okolo, (2011), viewed federal character as an instrument for eclectic redistribution of bureaucratic roles and industrial sites. He moves a bit further to say that federal character is based on the recognition of ethnic differences. Undoubtedly, any disclaim to the above assertion may not hold water because it is in the nature of federal order to device means of satisfying the ethnic groups within its domain otherwise unrest will definitely serve as a cog to the operation of the state just as it has brutally disrupted peace in the Darfur region of western Sudan. Abubakar, (2003), asserts that federal character principle is intending to build a sense of belonging and participation by the diverse ethnic groups and power seeking groups in the governance of the post-colonial state. He added that federal character was born out of anxieties and fear of domination that form the fabric of ethnoregional relations in Nigeria. He further stressed that federal character principle and its application in the governance in the Nigerian post-colonial state is symptomatic of the desire by the political class in the second republic to have easy access to and siphon the national wealth through patron-client linkages.

\section{Federal Character Principle in Federal Education Institutions}

Educational disparities between the North and Southern parts of Nigeria dates back to colonial era. For instance, in 1947, only 251 Northerners were in secondary schools, the figure represents just $2 \%$ of the total secondary schools enrolment in Nigeria. In 1965, secondary school enrolment in the North increased to 15,276 compared to 180,907 pupils enrolled in secondary schools in the South Coleman, (1958:134), Mustapha, (2004). The imbalance in terms of education between the North and South continued after independence. For example, in the 1969/70 academic session, only 19\% of the students in the Nigerian universities were from the Northern States, the Western States alone accounted for $48 \%$ of the students Orji, (2008). In the 1974/75 academic session, the Northern states had 24\% enrolment in the Nigerian Universities while the Southern states had $74 \%$ Orji, (2008:131). In the 2000/2001 session, the North had only $20 \%$ of the candidates admitted into Nigerian universities (Mustapha, 2004).

The South was ahead of the North in the production of skilled manpower that took over the public service after independence. For example, in the mid-1960s, the North had only $7 \%, 4 \%$ and $3 \%$ of the engineers, doctors and accountants in Nigeria respectively Orji, (2008:131).Similarly, in a research conducted by Adamu Mustapha, (2007:4), the Northern zones with 53\% of the population had only $10 \%$ of engineers, $15 \%$ of the professors,
$10 \%$ of the architects, $25 \%$ of the lawyers, $8 \%$ of bank executives and less than $2 \%$ of insurance practitioners. This translated to Southern predominance in both public and private spheres in the country.

\section{Federal Character and National Integration}

In view of the fact that Nigeria is a country of diverse religious and ethnic nationalities, it is strongly believed that introduction and application of federal character and its affiliate concepts are faced with certain problems, as opioned by Ahmadu Bello in 1960 found in (Ovolo, 2014):

The new nation called Nigeria should be an estate of our great grandfather Othman Danfodio. We must ruthlessly prevent a change of power. We use the minorities in the North as willing tools and South as conquered territory and never allow them to rule over us and never allow them to have control over our future".

Further prove was instructively recorded in 1986 when, a Sokoto Prince, Alhaji Shehu Malami and Alhaji Maitama Sule, one of the Nigeria's respected bureaucrats created a storm among southerners when they respectively informed their listeners of Hausas superiority. To their bewilderment (southerners), they were informed that they (Hausas/Fulanis) acquired their dark skin from inter-marriages with the local Africans and that they were endowed with leadership qualities (Okolo, 2014). The evils of tribalism in Nigeria are many. Tribal appellations cause tribal idiosyncrasies; these lead ultimately to variety and superciliousness and disharmony. A Hausa man may think a Yoruba man is inferior, while the Yoruba man in turn commonizes the Igbo; and Igbo man concedes to himself that both the Hausa and Yoruba are just the people without gut (Etekpe, \& Okolo, 2011).

The above quotations capture the reason and current situation in Nigeria due to ethnocentrism. An ethnic group is distinguished by language, culture, religion or both. Ethnocentrism is a self-judgment that one ethnic group is superior to others. Such assumption promotes antagonism evidenced in Nigeria. In response to many challenges orchestrated by ethnocentrism, Awolowo (1968) described Nigeria as divergently and almost irreconcilable entity. Drawing from the above quotations, principles of federal character, nation building and national integration are irreconcilable with the composition and attitude of most Nigerians. Nweke, (1995) described ethnocentrism as being attitudinal in form and perceptual in content. It is not easily erased particularly when the leaders do not display sufficient and convincing attitude that our strength lies in the diversity and exploration of resources for equitable benefit of every citizen irrespective of affiliation or originality.

\section{THEORETICAL FRAMEWORK: LIBERAL PLURALIST THEORY}

The liberal pluralist theory is adopted and used in this study to examine the impact of Federal Character Principles on National Integration in selected federal institutions in 
Adamawa State. The pluralist tradition is closely linked to the democratic aspirations of the western societies. The proponents of the theory are Harold Laski, (1893-1950), and Cole (1889-1959). The theory assumes that society is not monopolistic and can be divided into political, economic and social spheres. The pluralist convention is that individuals having shared attitudes and values come together to associate voluntarily, to promote their common interest and to achieve certain specific goals. According to the pluralist, there are hundreds or thousands of relatively and independent groups in society at one point in time. These groups may be best on ethnicity, language, religion, gender, region, province, ideology or class with leaders pursuing the goals of their members to achieve in either social, economic or political spheres. They argued further that power in a state is widely distributed among the various groups and that no single one can claim monopoly of power. Proponents of pluralism argue that this negotiation process is the best way to achieve the common good; since everyone can participate in power and decision making (and can claim part of the ownership of the results of exercising power) there can also be widespread participation and a greater feeling of commitment from society members, and therefore better outcomes.

For pluralism to function, be successful and define the common good, all groups have to agree to a minimal consensus regarding shared values, which tie the different groups to society, and shared rules for conflict resolution between groups. The most important is that mutual respect and tolerance, so that different group can coexist and interact without anyone forced to assimilate to anyone else's position in conflicts that will naturally arise out of diverse interests and positions. These conflicts can only be resolved durably by dialogue which leads to compromise and to mutual understanding.

The pluralist theory of state encourages situation where the state responsibilities, are shared among the various groups that make up the state so that no one can claim or enjoy monopoly of power over the other groups in the state. The theory still points out that these groups constitutes interests or goals which could either fall within the purview of economic, social or political and each of the groups work with determination to actualizes its goals.

Deducing from the above, theory vividly emphasised that the federal institutions should not be govern by few groups to dominate the helm of affairs to exclude other groups by denying them access to participation. This is because; this practice may tend to reinforce the perennial inter-ethnic chauvinism and bigotry which can seriously hamstrung the operation of the federal government institutions.

The justification thereto in selecting this theory is that the theory suggests an ideal state that will accommodate multiethnic groups or interest groups and contended that each of these groups have certain goals it intends to achieve. And finally, the theory concluded by saying power in the state should be distributed among the group which of course is a sort to peace and unity.

\section{METHODOLOGY}

This study adopts a descriptive survey research as its research design. Descriptive survey is the research design that helps in the collection of detail description of existing phenomenon with the intent of employing data to make more intelligent plan for improving. The descriptive survey design is a method that allows for collection of data in both quantitative and qualitative manner. The beauty of this is that "the researcher gathers both data and make interpretation as to whether the result from both data support or constructs each other “(Creswell, 2002: 563). According Creswell (2002) the reason for the use of multiple sources of data collection is for triangulation of data. The advantage of a survey design is that one data collection form supplies strength to offset the weakness of the other form.

\section{Data Collection and Sample}

While purposive sampling was used in selecting federal institutions in Adamawa State, random sampling technique was adopted to enable the researcher to select respondents randomly from the two selected federal institutions such that each respondent will have same probability of being chosen for interviews. To this end, simple random sampling is a method of survey sampling which enable the researcher to select randomly in order to represent the whole population. For the purpose of this research, Taro Yamani's simple sample formula was used to determine the sample of the study.

The population readily available for this study is that one the researcher intends to draw his sample as a sub-set of the population. A total of 200 questionnaires was distributed, 100 questionnaires for each institution.

\section{RESULTS AND DISCUSSION}

The aim of this chapter is to present the result of analysis and interpretation of the data collected through the questionnaire administered to the staff of the selected Tertiary institution in Adamawa state. This will lead to the data being reduced to intelligible and interpretable form so that the answer to the research questions can be found, and conclusion drawn. Data was analysed using the descriptive statistics and ANOVA.

\section{Respondent's rate of return}

Table: 4.2 Respondents rate of return

\begin{tabular}{|c|c|c|}
\hline Items & $\begin{array}{c}\text { Frequenc } \\
\mathrm{y}\end{array}$ & Percentage \\
\hline Questionnaire administered & 200 & 100.00 \\
\hline Questionnaire returned & 173 & 86.50 \\
\hline Questionnaire not returned & 27 & 13.50 \\
\hline Valid questionnaire & 152 & 76.00 \\
\hline Invalid questionnaire & 21 & 10.50 \\
\hline
\end{tabular}

Source: Field Data, (2020) 
Table 4.2 contained descriptive statistics of respondent's rate of return that shows a relatively high rate of return. A total of 200 copies of the structured questionnaire were distributed to cover the population of the two selected Federal tertiary institutions in Adamawa state. Out of this, 152 questionnaires were properly filled and returned. This represent $76 \%$ rate of return. The remaining 48 were either not returned or invalid.

\section{Characteristics of Survey Respondents}

Table: 4.1 Characteristics of the Survey Respondents

\begin{tabular}{|c|c|c|}
\hline Variables & Frequency & $\begin{array}{c}\text { Percentage } \\
(\%)\end{array}$ \\
\hline Gender & & \\
\hline Male & 87 & 52.2 \\
Female & 65 & 42,8 \\
\hline Age & & \\
\hline Below 20 years & 2 & 1.5 \\
21-30 years & 29 & 19.1 \\
31-40 years & 40 & 26.3 \\
41-50 years & 46 & 30.3 \\
Above 50 years & 35 & 23.0 \\
\hline Education Qualifications & & \\
\hline O level & 17 & 11.2 \\
OND/NCE & 40 & 26.3 \\
HND/Bachelor's Degree & 55 & 36.2 \\
Postgraduate & 40 & 26.3 \\
\hline Working Experience & & \\
\hline 0-5 years & 27 & 17.8 \\
6-10 years & 30 & 19.8 \\
11-15 years & 41 & 26.9 \\
16-20 years & 38 & 25.0 \\
Above 20 years & 16 & 10.5 \\
\hline
\end{tabular}

Source: Field Data, (2020)

The demography of the respondents taken include: gender, age, educational qualification, and working experience as contained in table 4.1. Majority of the respondents who took part in this study are male, that is $57.2 \%$, as against female who are $4203 \%$. On the age of the respondent, majority are between the ages of 41 to 50 years representing $30.3 \%$ followed by those who are between the age of 31 to 40 years ie. $26.3 \%$. the qualifications of the respondents are evenly distributed. Respondents that possess GCE/SSCE are $11.2 \%$, OND/NCE 26.3\%, HND/Bachelor's Degree $36.2 \%$ and postgraduate degree $26.3 \%$. Out of the 152 respondents, 27 representing $17.8 \%$ have $0-5$ years working experience, $19.7 \%$ 6-10 years, $26.9 \% 11-15$ years, $25.0 \% 16-20$ years and only 16 ie. $10.5 \%$ have more than 20 years of working experience.

\section{Descriptive Statistics}

Table 4.3 Compliance in appointment of principal officers

\begin{tabular}{|c|c|c|c|}
\hline & $\mathrm{N}$ & Mean & $\begin{array}{c}\text { Std. } \\
\text { Deviation }\end{array}$ \\
\hline $\begin{array}{c}\text { Level of awareness of federal } \\
\text { character principle }\end{array}$ & 152 & 3.4079 & .9653 \\
\hline $\begin{array}{c}\text { Principal officers are always } \\
\text { appointed based on the principles of } \\
\text { federal character }\end{array}$ & 152 & 3.5329 & .8450 \\
\hline
\end{tabular}

\begin{tabular}{|c|c|c|c|}
\hline $\begin{array}{c}\text { Federal character principles are set } \\
\text { aside when there is no qualified } \\
\text { candidates for principal officers }\end{array}$ & 152 & 3.4145 & 1.0512 \\
\hline $\begin{array}{c}\text { Outside influence affect strict } \\
\text { compliance with federal character } \\
\text { principles in appointment of } \\
\text { principal officers }\end{array}$ & 152 & 3.6908 & .7208 \\
\hline Valid N (listwise) & 152 & & \\
\hline
\end{tabular}

Source: Field Data, (2020)

Respondents were asked to indicate the level of their agreement with a number of elements of compliance in appointment of principal officers in federal tertiary institution, using a 5-point Likert scale of measurement. The summary of the findings is presented in table 4.5 above. The finding revealed that the respondents believed federal tertiary institution complied with federal character in appointment of principal officers.

Based on the analysis, respondents believed that principal officers are always appointed based on federal character principles with a mean of 3.533. However, the respondents also believed that outside influence sometimes affect strict compliance with federal character principles in appointment of principal officers in the federal tertiary institution with a mean of 3.69 .

Table 4.4 Compliance in staff employment

\begin{tabular}{|c|c|c|c|}
\hline & $\mathrm{N}$ & Mean & $\begin{array}{c}\text { Std. } \\
\text { Deviation }\end{array}$ \\
\hline $\begin{array}{c}\text { Staff employment are done based on } \\
\text { federal character principles }\end{array}$ & 152 & 3.3092 & 1.09927 \\
\hline $\begin{array}{c}\text { All the states of the federation are } \\
\text { truly represented in my institution }\end{array}$ & 152 & 2.9408 & 1.27239 \\
\hline $\begin{array}{c}\text { Principles of federal character are } \\
\text { violated when there are no applicants } \\
\text { for employment from other states }\end{array}$ & 152 & 3.2434 & 1.20703 \\
\hline Valid N (listwise) & 152 & & \\
\hline
\end{tabular}

The respondents' agreement with the institutions compliance with federal character principles in staff employment. Table 4.6 shows a summary of the findings, which shows that respondents didn't, agreed that federal tertiary institutions complied with federal character principles in staff employment. In fact, respondents believed that not all the staff of the federation are represented in their institutions with a mean 2.94. Furthermore, respondents believed that regardless of whether there are applicants from other states or not, federal character principles are violated in staff employment in the federal tertiary institution with a mean of 3.24.

Table 4.5 Descriptive Statistics of Compliance in students' admission

\begin{tabular}{|c|c|c|c|}
\hline & $\mathrm{N}$ & Mean & $\begin{array}{c}\text { Std. } \\
\text { Deviation }\end{array}$ \\
\hline $\begin{array}{c}\text { Students admission strictly follows } \\
\text { federal character principles }\end{array}$ & 152 & 2.8618 & 1.33744 \\
\hline $\begin{array}{c}\text { Admission requirements hinders } \\
\text { strict compliance with federal } \\
\text { character principles }\end{array}$ & 152 & 3.7368 & .75236 \\
\hline Valid N (listwise) & 152 & & \\
\hline
\end{tabular}


The respondents were asked to indicate the level of their agreement with compliance with federal character principles in student admission in federal tertiary institution. The summary of the finding is shown in table 4.5. According to the findings, the respondents agreed that their institutions are not complying strict with federal character principles in students admission. Their believed that admission requirement hinders strict compliance with federal character principles in their institution with a mean of 3.74 .

Table 4.6 Descriptive Statistics of Factors Affecting Compliance

\begin{tabular}{|c|c|c|c|}
\hline & $\mathrm{N}$ & Mean & $\begin{array}{c}\text { Std. } \\
\text { Deviation }\end{array}$ \\
\hline Ethnicity hinders compliance & 152 & 3.4539 & 1.09083 \\
\hline $\begin{array}{c}\text { Corruption hinders compliance } \\
\text { External influence hinders } \\
\text { compliance }\end{array}$ & 152 & 3.8026 & 0.67146 \\
\hline $\begin{array}{c}\text { Tribalism hinders compliance } \\
\text { Favouritism hinders compliance }\end{array}$ & 152 & 3.3684 & 1.08989 \\
\hline $\begin{array}{c}\text { Other factors hindering } \\
\text { compliance }\end{array}$ & 152 & 3.4342 & 1.07143 \\
\hline $\begin{array}{c}\text { Valid N (listwise) } \\
\text { Vald }\end{array}$ & 152 & & 0.75236 \\
\hline
\end{tabular}

Respondents were asked to indicate their agreement with the element of factors affecting compliance with federal character principles in their institution.

Result in table 4.6 indicates that respondents agree that corruption, ethnicity, favouritism and external influence hinders strict compliance with federal character principles in their respective institutions. Specifically, corruption hinders compliance with a mean of 3.8, while ethnicity, favouritism and external influence hinders compliance with means of $3.45,3.74$ and 3.37 respectively. Also, finding shows that other factors character principles in these institutions with a mean of 3.43 .

However, findings revealed that tribalism does not hinder compliance with federal character principles in the institution with a mean of 2.85 .

\section{ANOVA}

Table 4.7 ANOVA Analysis of factors affecting compliance with federal character principles

\begin{tabular}{|c|c|c|c|}
\hline Variables & Eta Square & $\begin{array}{c}\text { F - } \\
\text { Statistics }\end{array}$ & P - Value \\
\hline Ethnicity & 0.840 & 193.151 & 0.000 \\
\hline Corruption & 0.025 & 1.241 & 0.297 \\
\hline External Influence & 0.744 & 106.652 & 0.000 \\
\hline Tribalism & 0.516 & 39.194 & 0.000 \\
\hline Favouritism & 0.065 & 3.412 & 0.019 \\
\hline Other Factors & 0.841 & 193.693 & 0.000 \\
\hline
\end{tabular}

An ANOVA technique was used to evaluate the influence of the predetermined factors of compliance with federal character principles. Table 4.8 contained this analysis and the result indicates that ethnicity has significant positive influence on compliance with federal character principles as indicates by Eta square value of 0.840, F-statistics, 193.151 and P-value of 0.000. Also, external influence affect compliance with federal character principles with Eta square value of 0.744, Fstatistics of 106.652 and P-value of 0.000 indicating a significant effect. Again, tribalism was found to have significant positive effect on compliance with federal character principles with Eta square value of 0.516, Fstatistics of 39.194 and P-value of 0.000. Favoritism and other factors were also found to have a significant positive influence on compliance with federal character principles with Eta square value of 0.065 and 0.841 , F-statistics of 3.412 and 193.693 and P-value of 0.019 and 0.000 respectively. However, analysis shows that the relationship between corruption and compliance with federal character principle is insignificant with Eta square value of 0.025 , F-statistics of 1.241 and P-value of 0.297.

\section{Discussion}

Findings of this study revealed that federal tertiary institutions adhered to the principles of federal character in appointment of principal officers such as vice chancellors, rectors, provosts, registrars, bursars among others. This finding is in agreement with the finding of (Adeosun, 2011). However, there are violations of these principles in some instances due to some factors especially external influence from highly placed individuals. The study also found that federal character principles are followed during employment of a study by (Igbokwe-Ibeto, \& Aremo, 2013) also found the same. Despite complaints by some members of staff, the recruitment process generally follows the principles of federal character. Sometimes some states have zero applicants which mean no representative.

In the area of students' admission, federal character principles are considered to a certain extent, as the findings show significant adherence to the principles. This finding is also in line with the findings of (Adeosun, 2011). However, factors such as admission's requirements, lack of applicants from some states among others hinder strict compliance with the principles. Findings also show that ethnicity is a major stumbling block to strict compliance with federal character principles in federal tertiary institutions. This agrees well the finding of (Okolo, 2014). Also, tribalism hinders strict compliance with federal character principles in the institutions as found by (Okolo, 2014). External influence is another factor hindering strict compliance with federal character principles. A study conducted by (Adeosun, 2011) also found external influence to be a major hindrance to strict compliance with federal character principles. The study also found that favouritism hinders strict compliance with federal character principles in the federal tertiary institutions. This is in agreement with finding of (Adeosun, 2011). However, the study found that corruption does not hinder strict compliance with federal character principles in the federal tertiary institutions. This contradict the findings of the study by (Sanusi, 2012; Adeosun, 2011). 


\section{CONCLUSIONS AND RECOMMENDATIONS}

Federal character principles have received general acceptance from all and sundry as a normative expression of the equal right of all Nigerians to participate in the political, administrative and economic affairs of the country. Certainly, if Nigeria is to remain a federal unit, the utmost need to balance our diverse interests will continue to surface, therefore, the need for federal character to be employed to take care of this diverse and sometimes conflicting interest. Therefore, it is necessary to seek for ways and means to minimise the problems of poor implementation so as to ensure the overall progress of the country. It is obvious that the principle has assisted in reducing various elements of mutual mistrust and enmities among the different ethnic groups that make up the country.

This study has among other things found that there is high level of awareness of the principle of federal character among employees of federal institutions. This will help in the achievement of national integration. Findings also revealed that there seems to be strong and general acceptance amongst scholars that the whole essence of the establishment of the federal character principles as a policy measure for equitable distribution of governmental activities and employments in the country. The use of federal character in Nigeria remains an admirable policy mechanism of the federal government which can curb the perceived inequality and marginalization across the country but the practical implementation and interpretation of this policy is far from it main objectives.

Among the factors hindering strict adherence to these principles include ethnicity, tribalism, external influence, favouritism and to a considerable extent corruption. Looking at the factors that affect the smooth implementation, enforcement and strict compliance with the federal character principles in the federal institutions, we recommend that relevant provisions of the Constitution should be amended so as to make the federal character principle justiciable like other operative parts of the constitution. Also, strict adherence to policy guideline and implementation plans as spelled out in the Act establishing the federal character principles must be clearly followed in order to end inequality and marginalization. We also recommend that massive orientation and awareness is needed by the government to draw the intention of the general public to the major objectives of the federal character principles by this the citizens of Nigeria can awaken to what expect from the agency. Finally, an enforcement unit of the federal character principles should be strengthen in order to carryout it duty of ensuring equitable distribution of employment and fairness and sanction should be carryout on those institution that failed to adhere to the federal character principles in students admission, employment and promotion among others.

\section{REFERENCES}

[1] Adeosun, A. B. (2011). Federal Character Principle and National Integration: A Critical Appraisal. International Journal of Politics and Good Governance, 2(4), 1-13.
[2] Adesoji, A.O and Alao, A (2009). "Indigeneship and Citizenship in Nigeria; Myth and Reality', The Journal of Pan African Studies 2(9), 151-165.

[3] Babbie, E. (1986). The Practice of Social Research Ibadan; Alafas Publishing Company.

[4] Cole, G.D.H (1993). The Pluralist Theory of The State; London and Newyork ISBN 0-203-98600-8 master e-book ISBN

[5] Ezeibe, C. C (2013). Federal Character Principle and Nationality Question in Nigeria in International Journal of Research in Arts $\begin{array}{lllll}\text { and } & \text { Social } & \text { Sciences } & 2 & (2),\end{array}$ www.academicexellencesociety.comfederal_character_principle_a nd_nationality_quesion_in Retrieved from; _nigeria.html

[6] Etekpe, A. \& Okolo, P. O. (2011). Politics and Democracy in Contemporary Nigeria. International Journal of Social Sciences, 3(2), 23-32. ISSN 2141-873X.

[7] Center for the Promotion of International Relations, Studies and Development, Kandid Gold, Accra Ghana.www.ccsdev.org. Pp. $424-434$.

[8] Heirmexxy (2011). Federal Character Policy and Technology Development in Nigeria; Problems and Prospects www.Pristinethrills.blogspot.com/2011/03/federal-characterpolicy-and-technology/html

[9] Ibaba, S. I. \& Okolo, P. O. (2009). Resolving Militia conflicts in the Niger Delta: The Role and strategies of Mediation, Martins papers, Martins Institute Article 2:Retrieved from http://www.class.uidaho.edu/martin_archives/Martin\%20Papers.ht $\mathrm{ml}$

[10] Igbokwe-Ibeto, .J \& Aremo, M. O. (2013). "Federal Character and Recruitment in the Nigerian Civil Service: Prospects and Implications", Global Journal of Applied, Management and Social Sciences, 1(3), 34-45.

[11] Mustapha, A (2007) "Institutionalising Ethnic Representation: How Effective is the Federal Character Commission in Nigeria? Centre for Research on Inequality, Human Security and Ethnicity. Working Paper No 43 June. Also available online at http://www crise.oxac.uk

[12] Okolo, P. O. (2014). Managing Minority Problems in Nigeria: The case of the Ethnic Minorities of the Niger Delta Region.Journal of Economics and Sustainable Development, Vol. 5, No. 6, (2014).ISSN 2222-1700 (Paper) ISSN 2222-2855 (Online).IISTE USA.http://www.iiste.org/journals/index.php/JEDS/article/view/1 1938 or www.iiste.org. Pp. $91-99$.

[13] Onu, G. (2008). Contemporary issues in Nigerian Politics and Government and Implications for sustainable Development" in Nigerian Journal of Politics and Administration Vol 2 No 1 Enugu, New Generations Ventures.

[14] Olamolanye, F (1986) Reassert Method and Statistics Jos: Fab Annied Ltd.

[15] National Orientation Agency (2009). A survey of Nigeria Core Value, Ibadan Safa books Ltd.

[16] Sanusi, L. (2012)."Federal character breeds mediocrity" Retrieved from; http://ihenationonlineng.net/new/news/federal-characterbreedsmidiocrity-says-samusi/html.

[17] Sharma, M. P, Sadana, B. L. \& Herpreet, L. (2011). Public Administration in theory and Practice: Allahabad India KitabMahal Printing.

[18] Shivji, I. G (2009). Revisiting the Debate on National Autonomous Development". In Adejumobi, S. \& Olukoshi, A. The African Union and New Strategies for Development in African. Nairobi CODESRIA

[19] Shilgba,L. K. (2011)."Towards true Federation" Parrot Newspaper, 12 ${ }^{\text {th }}$ Oct,1960: www.nairaland.com/674760/towardstruefederation-middle-belt

[20] Shona, K. (2013). "National Integration: complete information on the meaning, features and promotion of national integration in India" www.preservarticles.com/201012271786/nationalintegration.html 